\title{
Egy ritka zoonosis: a Schistosoma turkestanicum vérmétely által okozott cercaria dermatitis Magyarországon
}

\author{
Juhász Alexandra dr. ${ }^{1}$ - Dán Ádám dr. ${ }^{2}$ - Dénes Béla dr. ${ }^{3}$, \\ Kucsera István dr. ${ }^{4}$. Danka József dr. $^{4}$ - Majoros Gábor dr. ${ }^{1}$ \\ 'Szent István Egyetem, Állatorvos-tudományi Kar, Parazitológiai és Állattani Tanszék, Budapest \\ NÉBIH Állat-egészségügyi Diagnosztikai Igazgatóság, ${ }^{2}$ Molekuláris Biológiai Laboratórium, \\ ${ }^{3}$ Immunológiai Laboratórium, Budapest \\ ${ }^{4}$ Országos Epidemiológiai Központ, Parazitológiai Osztály, Budapest
}

\begin{abstract}
Az állatokban sok mételyfaj él, amelyek lárvája a gazda bőrén keresztül fertózi azt. Ezek közül az ember szempontjából a legfontosabbak az emlősök vérmételyei, mert belőlük kerülnek ki az embert fertőzni képes vérmételyek is. Több fajuk a trópusi országok lakóinak rettegett schistosomosisát okozza, míg más fajok behatolnak ugyan az ember bőrébe, de adulttá nem válnak a testében. A mérsékelt égövben fóleg az utóbbi, bőrgyulladás formájában jelentkező infekció fordul elő. A mételylárvák eredete legtöbbször nem tisztázható, ezért általában sem orvosok, sem állatorvosok nem foglalkoznak a fertőzés forrásával. Szarvasokban élő mételyfajról bizonyítottuk be, hogy a régen „vízi rühösség”nek nevezett bőrbántalmat csigákból kirajzó cercariák okozzák. A Duna egyik árterén endemikus Schistosoma turkestanicum okozta dermatitis ritkán kerül orvos szeme elé, pedig informális közlések alapján úgy túnik, hogy rendszeresen előforduló tünet a métely élóhelyén lévő vizekben halászó vagy fürdőző embereken. Ráutaló kórelőzmény esetén indokolt a humán vérmétely-fertőzöttséghez hasonló szerológiai reakciót adó cercaria dermatitis eredetét kivizsgáltatni. Orv. Hetil., 2016, 157(40), 1579-1586.
\end{abstract}

Kulcsszavak: cercaria dermatitis, vízi rühösség, Schistosoma turkestanicum, vérmételyek, zoonosis

\section{A rare zoonosis in Hungary: cercarial dermatitis caused by Schistosoma turkestanicum blood-fluke}

Several trematodes that parasitize vertebrate animals utilize swimming aquatic larvae to infect the host percutaneously. The most important ones among these parasites are the blood-flukes of birds and mammals comprising species that are also zoonotic. Within this latter group are species that cause the bilharziasis or schistosomiasis of inhabitants of the tropical countries, and other trematode species that are able to penetrate human skin, but do not develop to an adult form of the worm in the body. In temperate climates this latter type of infection occurs mainly in the form of an unpleasant inflammation of the skin and is often called "swimmer's itch". In most of these cases, the origin of the larvae remains unexplored, the source of the infection is neglected by the medical or veterinarian practitioners. Herein we report for the first time in Hungary that the cause of such dermatitis was the cercariae of Schistosoma turkestanicum, which infected red deer (Cervus elaphus) in this country. The local name of this pristine disease is "water mange" and it occurs only in one of the floodplains of the Danube. On the basis of informal communication this symptom seems to be rather regular among people who do fishing or have a bath in the habitat of the bloodfluke. In the case of adequate anamnesis it is worth examining the origin of the cercarial dermatitis which may give cross-reactions with human schistosomiasis during serological tests.

Keywords: cercarial dermatitis, aquatic larvae, Schistosoma turkestanicum, blood-flukes, zoonosis

Juhász, A., Dán, Á., Dénes, B., Kucsera, I., Danka, J., Majoros, G. [A rare zoonosis in Hungary: cercarial dermatitis caused by Schistosoma turkestanicum blood-fluke]. Orv. Hetil., 2016, 157(40), 1579-1586.

(Beérkezett: 2016. május 3.; elfogadva: 2016. augusztus 3.) 


\section{Rövidítések}

$\mathrm{BALB} / \mathrm{c}=$ egy beltenyésztett laboratóriumi fehéregértörzs neve $;$ DNS = dezoxiribonukleinsav; ELISA = (enzyme-linked immunosorbent assay) enzimhez kötött immunoszorbens teszt; $\mathrm{IgG}=$ immunglobulin-G; $\mathrm{PCR}$ = polimeráz láncreakció; $\mathrm{WB}=$ Western blot fehérjét detektáló analitikai módszer

\section{A vérmételyek és a cercaria dermatitis kapcsolata}

A halak és más, vízben élő állatok különféle parazitái esetében elég gyakori a perkután fertőzési mód, és ez sok bennük élő mételyfaj (Trematoda) lárvájánál is előfordul $[1,2]$. Az evolúció folyamán a laposférgek közé tartozó mételyek néhány faja megőrizte a bőrön át történő fertőzés képességét még abban az esetben is, ha szárazföldi gerincesekben telepedett meg. A madarak és emlősök mételyei közül a keringési rendszerben élő vérmételyek (Schistosomidae) lárvái használják ezt az utat a gazdába való bejutáshoz, de természetesen ezek is csak az éppen vízben tartózkodó gazdájukat tudják ilyen módon megfertőzni [3]. Az ember is többnyire így fertőződik meg vérmételyekkel, noha elvileg az ivóvízzel is megtörténhet a mételyes fertőzés $[4,5]$.

Az állati és emberi vérmételyek között nincs éles határ. Míg a hidegvérú gerincesek véredényrendszerében éló mételyek soha nem okoznak az emberben semmilyen kórfolyamatot, az emlősök vérmételyei közül jó néhány Schistosoma faj az ember oly gyakori parazitájává vált, hogy az általuk okozott parasitosis a malária után a második leggyakoribb, élősködő okozta betegség lett a világon $[5,6]$. A Schistosoma fajok közül az afrikai eredetű $S$. haematobium és $S$. mansoni ma már elsősorban csak az emberekben él, míg például a $S$. japonicum és a $S$. mekongi fôleg emlős háziállatokat fertôz ugyan, de az ázsiai emberek sokaságában is előfordul $[5,7]$. Ugyanennek a genusnak néhány faja csak állatban képes kifejődni, de ha azok lárvája az ember bőrének közelébe jut, képes befurakodni abba, noha ott mindenképpen elpusztul. A madarak vérmételyeinek több fajáról is bebizonyították, hogy a vízben úszó farkos lárvájuk, az úgynevezett cercaria ez utóbbi módon viselkedik [8], ezért kijelenthetjük, hogy a melegvérü gerinceseket fertőző vérmételyek lárvái alkalmanként képesek lehetnek az ember bőrébe jutni.

Mivel a nem megfelelő gazdába jutott mételylárvák sorsa a biztos pusztulás, érthetetlennek túnő viselkedésük oka mindenképpen magyarázatot igényel. Evolúciós szempontból a vérmételyek még a közvetett fejlődésú mételyek (Digenea) ősi csoportján belül is primitívebb fajoknak számítanak, amelyek életmódját a vízi környezet határozza meg $[9,10]$. A külvilágra került fejlődési alakjaik ezért nem különösebben ellenállóképesek a különféle kedvezőtlen behatásokkal szemben. Így például a petéik, amelyek a kapillárisok falában megakadva és azt átfúrva, a szövetek természetes mozgása következtében hagyják el a gazda testét, nem sokáig maradnak egyben, hanem a külvilágon azonnal kikel a burkukból a csillós sejtekkel borított testú lárva, a miracidium. Ez a folyamat mindig vízben történik. A hosszú út alatt, amíg a vénákban élő mételytől eljut a lassan vándorló pete a béltartalomba vagy a vizeletbe - vagy halak esetében a kopoltyúba - a miracidium kifejlődik benne, és így nincs szüksége a gazda testén kívüli, hosszas barázdálódási folyamatra. A csillós lárvának órákon belül be kell furakodnia egy számára megfelelő köztigazdának alkalmas vízicsigába, különben elpusztul. Ezért nagyon aktívan úszkál, keresi a csigákat, és minden általa alkalmasnak vélt csigába igyekszik behatolni $[2,5]$.

Ugyanezt a stratégiát folytatja az a lárvaforma is, amelyik késóbb, ivartalan szaporodás eredményeképpen, a csiga testében képződik a miracidiumból, annak behatolását követő néhány hét alatt. Egy miracidiumból több száz olyan lárva képződik a csiga testében, amelyik mindegyike kifejlett métellyé válhat a végleges gazdában. Ez a Furcocercariának nevezett, villás farkú lárva kirajzik a csiga testéből, és neki is órákon belül adekvát, gerinces gazdát kell találnia, hogy túléljen. Noha a métellyel fertőzött csiga hosszú idő́n át, csoportokban bocsátja ki magából a cercariákat, az egyes cercariapéldányok rövid élettartamúak, ezért sietniük kell, hogy tovább tudjanak fejlődni. Megfelelő gerinces gazdájuk testanyagaihoz némiképp hasonló vegyületek érzékelése esetén igyekeznek behatolni az azt kibocsátó bármilyen objektumba, és ez gyakran a végzetüket okozza [2]. Gazdafelismerő képességük csekély hatékonyságát ellensúlyozza, hogy igen nagy számban képződnek a csigákban, tehát ez a stratégia előnyös a métely fennmaradása szempontjából.

Laboratóriumi kísérletekkel bizonyítható, hogy mind a miracidiumot, mind a cercariát félrevezethetik a hamis forrásból kibocsátott kémiai ingerek, ezért kísérleti körülmények között és a természetes életterükben is gyakran olyan állatba kerülhetnek, ahol továbbfejlődni nem tudnak [11]. Nyilván a különféle gerinces állatok bőrébe is bejuthatnak a számukra nem adekvát mételylárvák, de ezt a folyamatot mint megfigyelhetó kórtünetet csak emberen tanulmányozták. Az állati vérmételyek lárvái annál nagyobb valószínúséggel hatolnak be emberbe, minél közelebbi rokonságban vannak az emberi vérmételyekkel. Míg a gazdák saját vérmételyeinek lárvái általában nem okoznak bőrgyulladást, mert nem időznek sokat a bőrben, a rájuk nézve nem gazdaspecifikus mételyeik lárvái megrekednek a hám alatt vagy az irhában, és gyulladást indukálnak $[12,13]$.

A világ különféle tájain sokféle helyi néven nevezett cercaria dermatitis valódi oka a múlt század első fele óta ismert. Először Észak-Amerikában [14], majd Európában [15] írták le, és azóta a szakirodalma meglehetősen kiterjedt $[16,17]$. A cercariák behatolása helyén viszkető, vörös foltok képződnek a bőrön, amelyek később kis göbökké duzzadnak. Az egyre fokozódóan viszkető, égő érzés néhány napig is megmaradhat, végül a göbök eltûnnek, de némelyik savót tartalmazó hólyagocskává 
vagy pustulává alakul és felfakad [18]. Egyes helyeken a bántalom annyira endémiás és rendszeres a fürdőző emberekben, hogy megpróbálkoznak a csigák irtásával vagy eltávolításával [19]. A mérsékelt égövben a cercariák rajzása szezonális, de a melegebb vidékeken a lárvák megjelenésének ideje kiszámíthatatlan.

Természetesen, az emberben megtelepedő mételyfajok okozta vérmételykór sokkal súlyosabb következményekkel járó megbetegedés, mint a cercaria dermatitis [20], de ez utóbbi bántalom hatása sem lebecsülendő, például olyan emberek esetében, akik rendszeresen vízben tartózkodnak. A rizsföldeken dolgozók gyakran szenvednek ilyen bőrgyulladástól [21, 22], míg a nyugati világ országaiban a tópartok nyaralóvendégei leginkább a „swimmers' itch” néven ismerik e furcsa fertőzést [19]. Leggyakrabban a vízi madarak vérmételyeinek cercariái okozzák a bántalmat, de okozhatja emlősállat vérmételye is $[8,11]$.

\section{A „vízi rühösség” hazai története}

A cercaria dermatitis feltehetőleg első hazai szakirodalmi említése Kotlán Sándor nevéhez füződik, aki „Parasitologia” címú könyvében neves külföldi szerzők munkái alapján röviden ír e kórképről [23]. Tudomása volt Cort 1928-as cikkéről is [14], amelyben a szerző a világon először ismerte fel a cercariákat az ilyen típusú bőrgyulladás okaként. Ebben a magyar állatorvosi tankönyvben és annak következő három kiadásában Kotlán még nem említ hazai esetet, de a könyv 1972-ben megjelent negyedik kiadásában, amely már Kobulej Tibor közremúködésével és számos kiegészítésével készült el, szerepel a gemenci halászok „vízi rühösség”-ére való utalás a vérmételyekről szóló fejezetben [24]. A szerzők feltételezik, hogy ezt a bántalmat is cercariák okozzák, de többet nem szólnak róla. Erre a magyar köznyelvi betegségnévre több utalás nem is található a szakirodalomban, talán azért, mert mind az orvosok, mind az állatorvosok érdeklődési körén kívül esett. Ha olykor szakértő szem elé is került néhány ilyen fertőzési tünet, annak orvoslása során minden bizonnyal az enyhe fokú bőrtünetek kezelésének általános szabályai szerint jártak el, és nem firtatták annak eredetét.

A cercaria dermatitisnek a gemenci ártéren való előfordulása a ma is ott élő emberek elmondásából bizonyosra vehető. Azt nem tudjuk, hogy a Duna mellékén csak alkalmilag kiránduló vagy a strandoló emberek tapasztalták-e magukon ezeket a tüneteket, de az biztos, hogy a helyi lakosság jelentős része ismeri ezt a bántalmat. Vadászokat, halászokat és a Sármellék falvaiban élő embereket megkérdezve azt tapasztaltuk, nagyon sokan hallottak a nyár végén jelentkező furcsa bőrkiütésekről, amit ott „sinnyetegesség”-nek, vagy „sinnyeteg kór”nak neveztek. Ezzel a ma már alig ismert szóval a magyar nép rühszerű bőrelváltozást nevezett meg, amiről azt tartották, hogy nedves helyen élő füvek érintése okozza [25]. Manapság már kevés olyan helyi lakossal lehet talál- kozni, aki önmaga el is szenvedte ezt a bántalmat, mert a gumicsizmák és kesztyúk használatának elterjedése ritkává tette az előfordulását.

Melyek is voltak azok az alkalmak, amikor a vízzel való kontaktust követően kialakult a bőrpír, a viszketés, majd a göbök? Azok, akik ilyen bőrkiütést szereztek, nem szívesen beszéltek róla, mert nemegyszer tilosban jártak az ilyen alkalmakkor: például az ár levonulása után, a sekély vízben kézzel fogták a halat, vagy esetleg olyan helyeken halásztak vagy fürödtek, ahol nem lett volna szabad. Mindamellett ettől függetlenül is, férfiember nem mutogatta pattanásos kezét-lábát senkinek, „hisz’ az is olyan volt, mint a szúnyogcsípés". Részben szégyellték is a bőrpírt, vagy nem is törődtek vele, ezért nem fordultak ilyen esetben orvoshoz. Arról is van helyi anekdota, hogy iskolakezdés előtt felkeresték a lurkók a bőrkiütés kialakulására lehetőséget adó helyeket, és szándékosan megfürödtek ott, hogy a bőrbántalom ürügyén néhány napig elkerülhessék az iskolát. Emiatt inkább csak azoktól a személyektől kaphatunk bővebb információt az esetek gyakoriságáról, akiket arra kértek, hogy a helyi orvos tudta nélkül szerezzenek be gyógyszert a tünetek enyhítéséhez, hogy ne kerüljön nyilvánosságra az elszenvedett „kórság”.

A megkérdezett személyek elmondásából összerakható az a kép, hogy a „sinnyetegességet” mindig sekély, pangó vízben kapták az emberek, és utána elég pontosan tudták, hogy az egy bizonyos helyen való tartózkodás során következett be, tehát helyhez volt köthető. Egyértelmü, hogy fóleg árkokban, csíkfogás vagy rákászás közben, tavakban vagy holtágban megrekedt halak összeszedegetésekor lehetett elszenvedni ezt a bőrgyulladást, általában a nyár legmelegebb időszakaiban, amikor mezítláb lehetett a vizekben tartózkodni. Sokan a hínárok tüskéinek tulajdonították a „csípéseket”, de a legtöbben magyarázatot sem kerestek rá. A múló bántalmat nem érdemesítették arra, hogy bárkinek is előhozakodjanak vele, és ezért még a körzeti orvosok is inkább csak a szóbeszéd alapján ismerték, semmint a páciensek közvetlen vizsgálata révén.

Annak ellenére, hogy a cercaria dermatitist elszenvedett emberektől többé-kevésbé hiteles adatokat lehetett szerezni arról, hogy a fertőzésük pontosan hol is következett be, saját vizsgálataink alkalmával a megnevezett helyeken általában nem találtuk nyomát olyan feltételeknek, amelyek a cercariák megjelenésére kedvezőek lettek volna. Ez arra utalt, hogy a fertőzés alkalmilag lokalizálható ugyan, de mind időben, mind térben sporadikus, és csak bizonyos körülmények között jelentkezik.

Az utóbbi években cercaria dermatitisre utaló, a vízben való tartózkodást követő szórványos bőrgyulladás több emberben is elöfordult, de ezek a tünetek kivizsgálásra nem kerültek, így néhány, fertőzést szenvedett személyről csak szóbeli közlés útján szereztünk tudomást. $\mathrm{Az}$ orvosi szakirodalom hazai esetet nem ismer, s noha parazitológiai tárgyú kézikönyv tárgyalja a témát [18], átfogó jellegü, kifejezetten dermatológiával foglalkozó 
szakkönyv még meg sem említi azt [26]. Korábban a témával kapcsolatban ilyen eset kapcsán született egy tudományos ismeretterjesztő cikk a Halászat folyóiratban, ami egyben az első magyar nyelvű, nyomtatásban megjelent közlemény volt erról a kórképrôl [27]. Mivel akkor a bántalom eredetét nem lehetett teljes bizonyossággal megállapítani, orvosi folyóirat nem vállalta az eset közlését.

\section{A Schistosoma turkestanicum külföldi és magyarországi elterjedtsége}

Egy amerikai eredetû métely, a Fascioloides magna a múlt század végén erőteljesen terjeszkedni kezdett a Duna árterein élő agancsos vadakban [28], és ezért többen is vizsgálni kezdték a szarvasfélék parazitáit. A gemenci szarvasok májmételykórjának vizsgálata során, 2002-ben megállapították, hogy az állatok májában nem ritka parazita a Schistosoma turkestanicum vérmétely, ami fóleg Közép-Ázsiában elterjedt a tülkös szarvú kérődzőkben [29]. A faj eredeti elterjedési területe Koreától Törökországig húzódik az ázsiai kontinens középső sávjában. E sokféle állatot fertőzni képes métely cercariái gyakran okoznak cercaria dermatitist a vízzel elárasztott földeken dolgozó emberek bőrében fóleg Kínában és Iránban [5, 22]. A métely magyarországi felfedezése előtt nem volt adat arról, hogy szarvasban is megtelepedhet ez a parazita. Eleinte valószínűnek tünt, hogy emberi tevékenység következtében létrejött behurcolás révén került be az országba, de a gemenci példányok DNS-szekvenciái oly nagymértékben különböztek az ázsiai példányok szekvenciáitól, hogy annak alapján a métely magyarországi őshonosságát kellett feltételeznünk [30]. A magyarországi Duna-szakasz déli része mentén elterjedt mételyt e területeken kívül még sem mi és - tudomásunk szerint a környező országokban mások sem találták még meg, ami a féreg nagyfokú endemikusságára utal.

Az ország különböző területeiről származó néhány mintát leszámítva, a gemenci szarvasokon kívül eddig nagyobb számban csak a szigetközi Duna-ártér szarvasaiból származó máj- és ürülékmintákat vizsgáltuk, de azokban a $S$. turkestanicum jelenlétét nem tudtuk kimutatni. Mivel a Szigetköz hasonló élőhely a szarvasok számára, mint Gemenc, a métely ottani hiánya megerősíteni látszik azt a feltevést, hogy a parazita csak a gemenci ártéren honos. Ha azonban a Duna árterén előforduló $S$. turkestanicum métely valóban őshonos, és a faj teljes elterjedési területén belül csak itt él a gímszarvasban, akkor a magyarországi populációt szigorúan gazdaspecifikusnak és izolálódott endemizmusnak kell tekinteni. Ezek után magától értetődően adódott, hogy a gemenci „vízi rühösség” okát benne keressük, és bizonyítsuk az emberi és állati bántalom összefüggését.

\section{A gemenci $S$. turkestanicum, mint a „vízi rühösség” lehetséges okozója}

A szarvasok vérmétely-fertőzöttségének felismerése óta eltelt tíz év alatt nagyon kevés helyet találtunk az ártéren, ahol a $S$. turkestanicum magyarországi köztigazdája, a Radix auricularia csiga rendszeresen előfordulna. A rövid életü, 3-4 centiméter nagyságúra is megnövő, vékony héjú vízicsiga élő példányai csak a nyári hónapokban találhatók meg, de a vizek időszakos változékonysága miatt többnyire minden évben más és más helyeken, és más és más időszakokban. Szerencsére a Decstől keletre fekvő Feketeerdő területén, a Gyepes-lapoknak nevezett, alacsonyan fekvő, időszakos tavak egyikében meglehetős rendszerességgel lehetett megtalálni a $R$. auricularia csigákat, s közülük néhány példányban meg tudtuk figyelni a $S$. turkestanicum cercariák kirajzását.

Meggyőződtünk róla, hogy a jellegzetes anatómiai felépítésük alapján felismerhető cercariák órák alatt képesek behatolni az egér bőrébe, majd egy hónap alatt patens fertőzést hoznak létre benne (1. ábra). Kísérleti állatokban és természetes körülmények között fertőződött rágcsálókban, a májban válnak kifejlett métellyé, de azt nem tudjuk, hogy ezek a kisemlősök szerepet játszanak-e a métely fenntartásában. Mindenesetre egy laboratóriumban fertőzött egér szövettani vizsgálata azt bizonyította, hogy a gemenci $S$. turkestanicum lárvája is képes akcidentális gazdákba behatolni, s ez megerósítette azt a gyanúnkat, hogy ez a métely felelős az emberi dermatitisek kialakulásáért.

Mivel a törékeny héjú $R$. auricularia nem a pocsolyákban él, hanem a mélyebb, nyílt vizek lebegő hínárjának lakója, csigagyújtés közben sokat kell gázolni a tavacskák vizében. Egyikünk (M. G.) a köztigazdákat keresve számtalan alkalommal tartózkodott már a gemenci Duna-ártér megannyi vízfolyásában és tavában, de korábban soha semmilyen bőrtünetet nem tapasztalt magán, mígnem 2014 júniusában azon a helyen, ahol a vérmételyhordozó csigákat sikerült megtalálni, jellegzetes kiütéseket szerzett csigagyüjtés közben. A lábon kialakult bőrpír és apró, viszkető hólyagok a csalánkiütéshez hasonló megjelenésűek voltak, és ott voltak gyakoribbak, ahol a bőr a vízfelszín közelében volt (2. ábra).

A fertőzést követő 2 . napon a gyulladt bőrterület felületéról vett kaparék PCR-vizsgálata megerősítette a $S$. turkestanicum nukleinsavának jelenlétét a bőr felszíni rétegeiben, de a bőrkaparékban a cercariák maradványait mikroszkóppal már nem lehetett felismerni. A tóban élő különféle csigákban többféle métely cercariái is megtalálhatók voltak, amik a bőrre tapadtak, ezért a bőrkaparék PCR-vizsgálata a $S$. turkestanicumon kívül más mételyfajok jelenlétét is kimutatta. Emiatt további vizsgálat volt szükséges a $S$. turkestanicum patogenitásának bizonyítására.

A fertőzést szenvedett személy vérsavója agargél-immundiffúziós próbában reagált a $S$. turkestanicum cercariákból kinyert antigénnel. Mivel ez a precipitáció a 


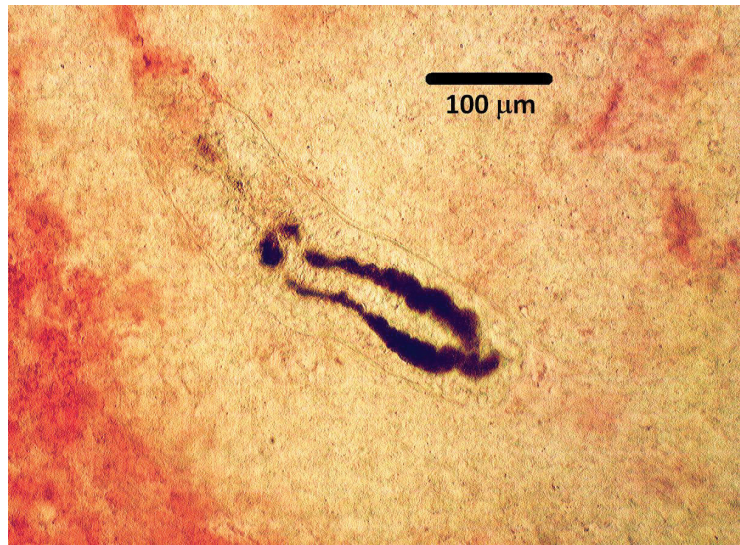

1. ábra

Schistosoma turkestanicum fiatal, hím példánya a kísérletesen fertôzött egér szétlapított májszövetében. A villásan elágazó, két bélág emésztett vérrel telt, a színtelen test kontúrja halvány (Friss, natív preparátum)

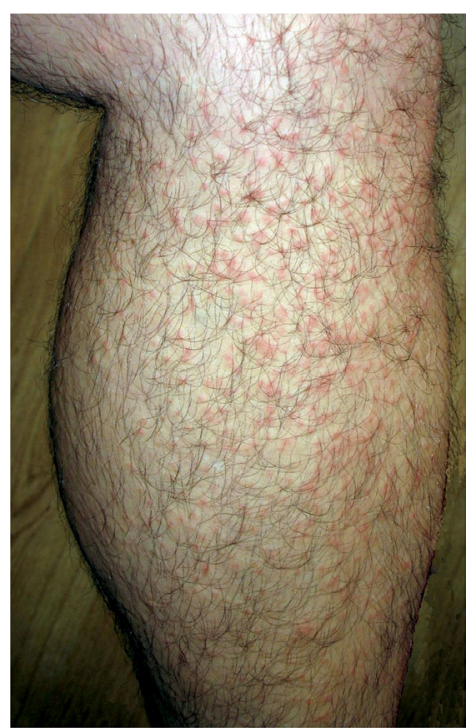

2. ábra

Természetes fertőzés következtében létrejött cercaria dermatitis lábszáron

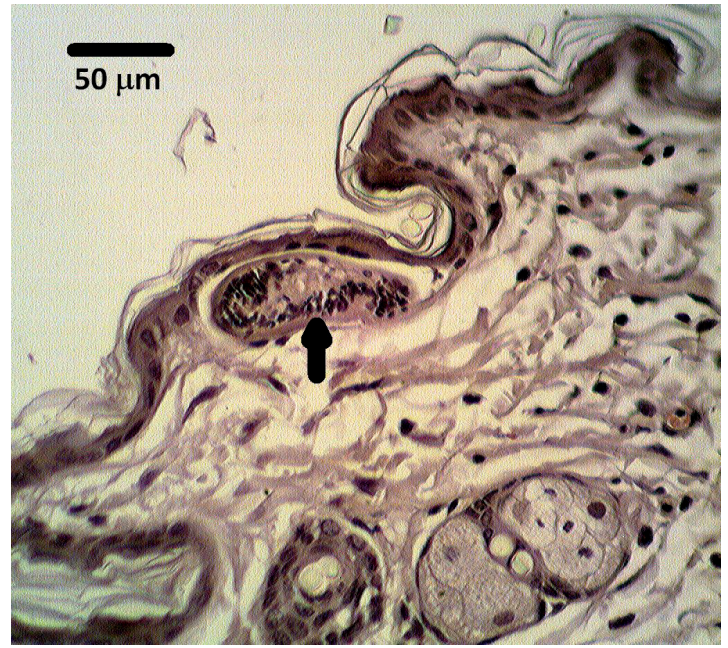

3. ábra

Schistosoma turkestanicum cercariájának feji vége (nyillal jelölve) a mesterségesen fertőzött egér hasbőrének elszarusodó hámja alatt (Szövettani metszet, hematoxilin-eozin festés)

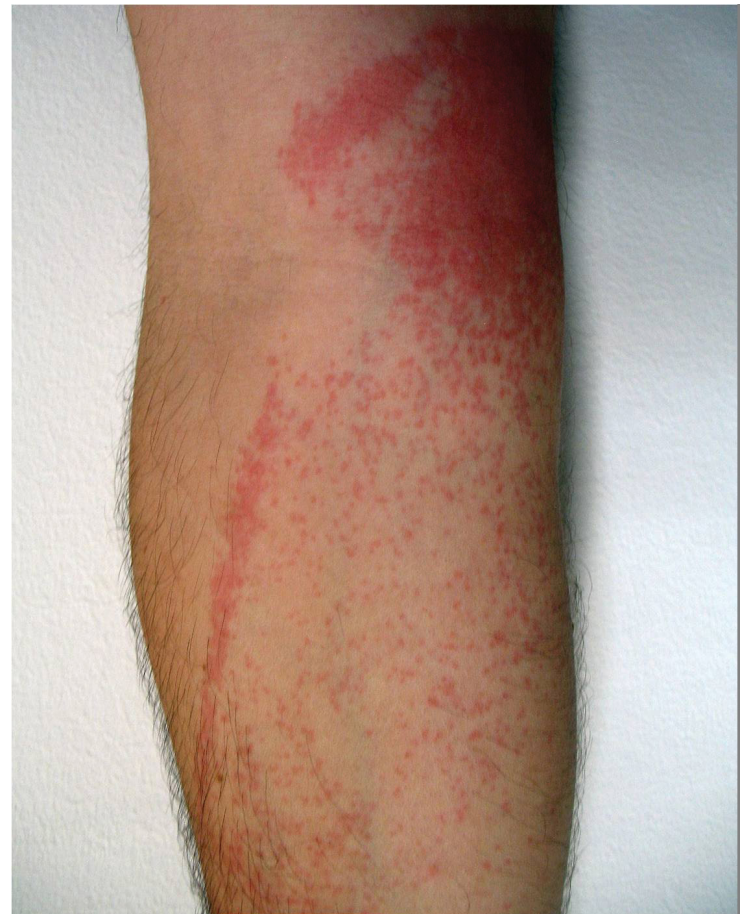

4. ábra

A Schistosoma turkestanicum cercariáival történt mesterséges fertőzés következtében kialakult dermatitis a kar bőrén a cercariák behatolása után egy nappal

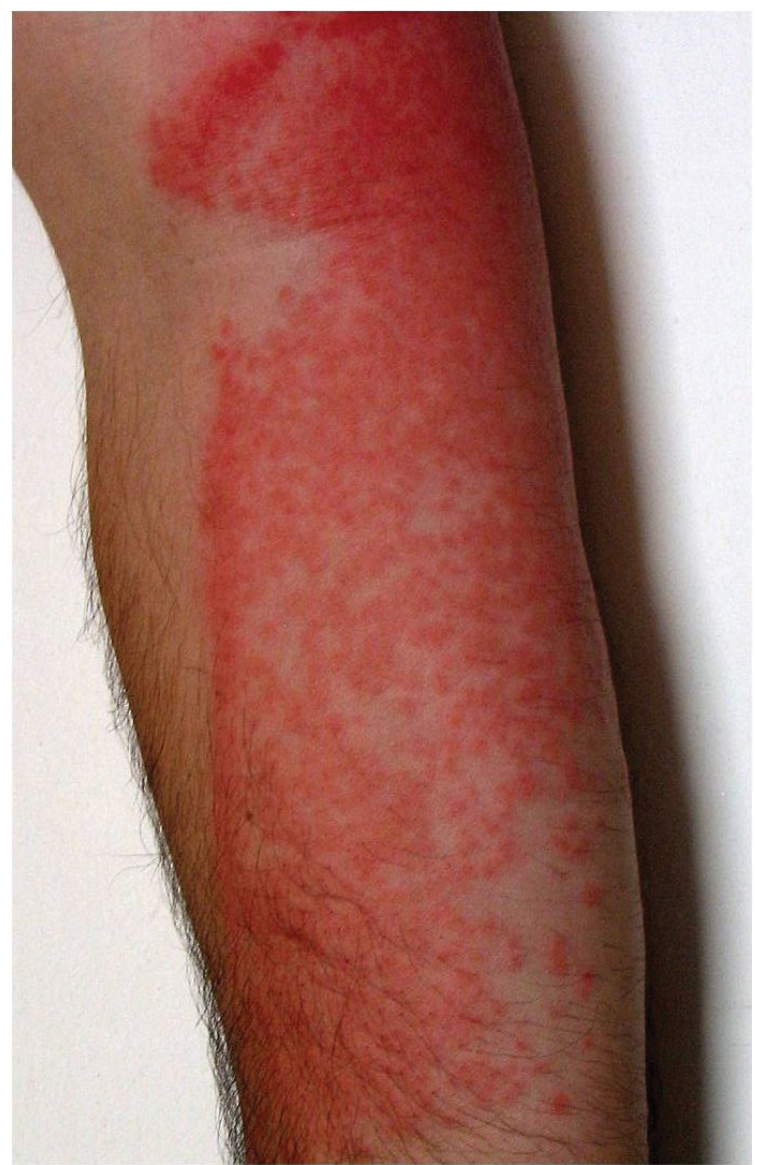

5. ábra

A Schistosoma turkestanicum cercariáival történt mesterséges fertőzés következtében kialakult dermatitis a kar bőrén a cercariák behatolása után három nappal 
szarvasokban élő Fascioloides magna mételyből kinyert antigénnel is megfigyelhető volt, a reakció specificitása nem volt bizonyítható.

\section{A S. turkestanicum cercariák dermatitist okozó képességének bizonyítása}

A természetes úton szerzett cercaria dermatitis alkalmával egyidejúleg Gemencen gyújtött $R$. auricularia csigák közül mindössze két példányból lehetett a jellegzetes, villás farkú cercariákat kirajoztatni. Ennek nemcsak az volt az oka, hogy eleve kevés példány tartalmazott $S$. turkestanicum lárvákat, hanem az is, hogy a mételylárvával fertőzött csigákat nagyon nehezen lehet életben tartani laboratóriumi körülmények között. Az élőhelyükről gyüjtött csigák egy részében a mételylárvák még nem érték el azt a fejlődési állapotot, amikor cercariaként elhagyhatták volna a köztigazda testét, de ezek is elpusztultak a cercariák érése előtt.

A kirajzóképes állapotban lévő cercariákat hordozó csigákat klórmentesített csapvízben tartottuk életben, és az ablakon át jövő természetes napfénnyel világítottuk meg, hogy ne befolyásoljuk azt a fényperiódust, amelyet az élőhelyén megszokott. A cercariák emissziója a reggeli órákban volt a legintenzívebb, de nappal bármikor lehetett cercariát nyerni a csigákból, ha azokat cercariamentes vizet tartalmazó edénybe helyeztük át. Egy-egy csiga tartóedényébe kibocsátott cercariák nagyságrendje naponta az ezres nagyságrendet elérte. Intenzív mozgásuk miatt a tényleges mennyiségüket csak elölésük után lehetett volna megbecsülni, de a cercariákat fertőzési kísérletre használtuk fel.

A frissen kirajzott cercariákat tartalmazó vizet l centiméter magasságú rétegben egy lapos müanyag edénybe öntöttük és abba egy kifejlett BALB/c egeret helyeztünk, fél órán keresztül. A víz az állat alsó testfelületével érintkezett. Ezután az egyébként semmilyen rendellenes tünetet nem mutató állatot éteres kloroformmal túlaltattuk, és az egész állatot 5\%-os pufferelt formalinba helyeztük. Egynapos fixálási idő után az állat hasbőrét lenyúztuk, végtagjait lemetszettük, és pufferelt formalinban tovább fixáltuk. A teljesen fixált szervekből hematoxilineozinnal festett szövettani metszeteket készítettünk. Mind a has, mind a végtagok bőrében meg lehetett találni a cercariaátmetszeteket, a szaruréteg alatt a hámban vagy az irha és a hámréteg határán (3. ábra).

A kirajzott cercariák zömét kísérletes emberi bőrgyulladás előidézésére használtuk fel, mert az adott technikai lehetôségek között ez volt az egyetlen lehetősége annak, hogy bizonyítsuk azok humán szervezetbe való behatolási képességét. A cercariákat tartalmazó vizet alkarnyi hosszúságú múanyag kádba öntöttük, majd egyikünk, aki már korábban cercariafertőzést szenvedett, 120 másodpercig tartotta benne alkarjának alsó felületét. Viszketési tünetek már a vízbe merítési periódus második fele alatt tapasztalhatók voltak, de a bórpír csak órák múlva kezdett kialakulni. Egy nap múlva a cercariák nagy száma következtében miliaris és egybefüggő bőrgyulladás alakult ki a bőrnek azon a részén, amely a vízzel érintkezett. A dermatitis határa pontosan kirajzolta a vízfelszín határát, és ehhez a vonalhoz közel volt a legsűrúbb a pontokból kirajzolódó elváltozás (4. ábra). Ez annak a következménye volt, hogy a vérmétely-cercariák mindig a vízfelszín közelében igyekeznek tartózkodni.

A karon tapasztalható piros foltok egy része a fertőzés utáni harmadik napra megnövekedve összefolyó bőrpírt hozott létre (5. ábra). Gombostúfejnyi duzzanatok is kialakultak, majd pár nap múlva ezek a fehéres papulák száraz hámgöbökké sorvadtak össze. A kifejezett bőrpír egy hétig állt fenn. A viszketési inger a fertőzés napján fokozódott, ezután csökkent és harmadnap már csak érintéssel volt kiváltható. A karon lévő elváltozás egy hétig markánsan, aztán alig láthatóan volt észlelhetô, majd két hét múlva csak a bőr egyenetlensége utalt a korábbi elváltozásra.

A természetes és kísérletes cercaria dermatitist elszenvedett személy szerológiai vizsgálatára pontosan az utóbbi fertőzést követő egy év múlva került sor. A fertőzés után két héttel és az egy év múlva levett vérminták NovaLisa Schistosoma mansoni IgG ELISA kittel (NovaTec Immundiagnostica GmbH, Németország) (S. mansoni antigén) erősen pozitív eredményt adtak. Ugyanezen vérminták a Schistosoma Western blot IgG (Ldbio Diagnostics, Franciaország) vizsgálat során negatívak lettek. Ugyan mindkét teszt $S$. mansoni eredetú antigént használ, de a specifikusabb WB lehetővé tette a fals pozitív ELISA-eredmény kizárását. Ennek alapján kijelenthettük, hogy a vizsgált vérmintában a Schistosoma genus fajainak közös antigénjeivel reagáló ellenanyag van. Mivel ez nem származhatott másból, csak a $S$. turkestanicum lárváival való kontaktust követő szerológiai áthangolódásból, igazoltnak látjuk, hogy ennek a vérmételynek a cercariái a bőrbe hatoltak és szerokonverziót hoztak létre.

\section{A magyarországi vérmételyek kutatásának jelentősége}

A megfigyelések és az elvégzett vizsgálatok tükrében bizonyítottnak látjuk, hogy a gemenci ártéren gyakori, vízzel való kontaktust követő emberi dermatitisek okozója a szarvasokban élő $S$. turkestanicum. Feltehető, hogy más mételyek cercariái is okoznak hazánkban hasonló bőrgyulladásokat, és az sem kizárható, hogy ez az emlősvérmétely a gemenci erdőkön kívül máshol is jelen van Magyarország területén. A cercariák okozta bántalom gyógykezelés nélkül is tünetmentesen gyógyul, ha baktériumos szövődmény nem társul hozzá. Indokolt esetben azonban a specifikus diagnózisra szükség van, ami a fent elmondottak alapján nem mindig könnyen elérhető.

A bántalom mértéke nem éri el azt a szintet, hogy biopsziás vizsgálattal lenne érdemes kideríteni a pontos okát, ezért az utólagos szerológiai vizsgálatok inkább szóba jöhetnek a járványtani nyomozás eszközeként, 
mint az azonnali diagnózist adó különféle módszerek. Ennek ellenére érdemesnek tartjuk a szerológiai vizsgálatok elvégzését az ilyen bőrtüneteket mutató pácienseken, hogy adatokat szerezzünk a dermatitist okozó mételyfajok elterjedtségének mértékéről és élőhelyéről. Mivel a szerológiai vizsgálatnak nem kuratív, hanem járványtani jelentősége van, nemcsak dermatitisben szenvedő pácienseken, hanem olyan embereken is célszerü elvégezni, akik a potenciálisan fertőzött területeken élnek, és munkájuk révén jobban ki vannak téve az ilyen módon létrejövő dermatitisnek, mint az átlaglakosság.

Magának a $S$. turkestanicum vérmételynek az elterjedtsége és az életfeltételei azért is érdekesek számunkra, mivel azok megismerése által következtethetünk a valódi emberi vérmételyek tulajdonságaira is. Amíg ez utóbbiak élőhelyén a kutatók számára is veszélyes lehet a mételyek tanulmányozása, a $S$. turkestanicum tanulmányozása viszonylag veszélytelen körülmények között oldható meg, és modellként használható a trópusi schistosomák tanulmányozásához. Az emberi schistosomák elterjedési területein már azért is nehéz ilyen kutatásokat végezni, mert ott az egyszerű dermatitist okozó vérmételyek és a vérmételykórt okozó állati vérmételyek egyaránt okozhatnak ilyen bőrtüneteket, tehát az epidemiológiai oknyomozás bonyolult feladat.

Emberi vérmételykórt olykor hazánkban is detektálnak olyan páciensekben, akik e bántalmat okozó férgek endemikus területeiról érkeznek Magyarországra [Kucsera I., szóbeli közlés]. Abban sem lehetünk biztosak, hogy az emberi schistosomák köztigazdáit nem hurcolják-e be egyszer az országba, hiszen például a Schistosoma mansoni egyik köztigazda csigáját már behurcolták Közép-Európába, s elszaporodott egy meleg vizű forrásban [31]. Fel kell készülnünk a schistosomosis korszerú diagnosztizálására a fertőzött személyek minél előbbi felismerése és a fertőzés terjedésének megelőzése miatt is. Ezért az adekvát diagnózis érdekében az állati és az emberi schistosomák okozta szerokonverziót pontosan meg kell különböztetni egymástól. Mint esetünk is mutatja, a csupán nem emberi vérmételyek okozta cercaria dermatitist elszenvedett személyek szerológiai vizsgálatának eredménye adott esetben félrevezető lehet, ha nem elég alapos a vizsgálat. Ilyen okok miatt hasznosnak éreznénk, ha a gyakorló orvosok és a diagnosztikai laboratóriumok az egészségügyi hatóságok támogatásával jártasságot szereznének a jelentéktelennek vélt cercaria dermatitises esetek felismerésében.

Anyagi támogatás: A szerzők a Gemenci Erdő- és Vadgazdaság Zrt. anyagi támogatásában (MG) és az Állatorvos-tudományi Doktori Iskola PhD-ösztöndíjában (J. A.) részesültek. Az elvégzett vizsgálatok részben az Emberi Erőforrások Minisztériuma 9877-3/2015/FEKUT számú támogatási szerződésének keretében valósultak meg.
Szerzői munkamegosztás: J. A., M. G.: A cikk megszövegezése, terepvizsgálatok, fertőzési kísérletek és irodalmazás. D. B., K. I., D. J.: Szerológiai vizsgálatok. D. Á.: Molekuláris biológiai vizsgálatok. A cikk végleges változatát valamennyi szerző elolvasta és jóváhagyta.

Érdekeltségek: A szerzőknek nincsenek a jelen közleménynyel kapcsolatos érdekeltségeik.

\section{Köszönetnyilvánítás}

A Gemenci Erdő- és Vadgazdaság Zrt. a terepen végzett munkához többéves anyagi és nélkülözhetetlen logisztikai támogatást nyújtott. Ezenfelül a szerzők köszönettel tartoznak a gazdaság vadászainak, erdészeinek és több más munkatársának személy szerint is a számos területen nyújtott közvetlen segítségükért.

\section{Irodalom}

[1] Haas, W.: Parasitic worms: strategies of host finding, recognition and invasion. Zoology, 2003, 106(4), 349-364.

[2] Haas, W.: Physiological analyses of host-finding behaviour in trematode cercariae: adaptations for transmission success. Parasitology, 1994, 109(Suppl.), S15-S29.

[3] Loker, E. S.: A comparative study of the life-histories of mamma lian schistosomes. Parasitology, 1983, 87(2), 343-369.

[4] Giver, H., Johansen, M. V., Christensen, N. O., et al.: Peroral infection of pigs with Schistosoma japonicum cercariae. Vet. Parasitol., 1999, 83(2), 161-165.

[5] Malek, E. A.: Snail-transmitted parasitic diseases. Vol. I. CRC Press, Boca Raton, Florida, 1980.

[6] Goater, T. M., Goater, C. P., Esch, G. W.: Parasitism: The diversity and ecology of animal parasites. 2nd ed. Cambridge University Press, Cambridge, 2014.

[7] Miyazaki, I.: An illustrated book of helminthic zoonoses. International Medical Foundation of Japan, Tokyo, 1991.

[8] Horák, P., Mikeš, L., Rudolfová, J., et al.: Penetration of Trichobilharzia cercariae into mammals: dangerous or negligible event? Parasite, 2008, 15(3), 299-303.

[9] Price, E. W.: A synopsis of the trematode family Schistosomidae with descriptions of new genera and species. Proc. U.S. Natl. Mus., 1929, 75, 1-39.

[10] Yamaguti, S.: A synoptical review of life histories of digenetic trematodes of vertebrates. Keigaku Publishing Co., Kyoto, 1975.

[11] Picard, D., Jousson, O.: Genetic variability among cercariae of the Schistosomatidae (Trematoda: Digenea) causing swimmer's itch in Europe. Parasite, 2001, 8(3), 237-242.

[12] Haas, W., Granzer, M., Brockelman, C. R.: Finding and recognition of the bovine host by the cercariae of Schistosoma spindale. Parasitol. Res., 1990, 76(4), 343-350.

[13] Ševcová, M., Kolaŕová, L., Gottwaldová, A., et al.: Cercarial dermatitis. [Cerkariová dermatitida.] Ceskoslov. Dermatol., 1987, 62, 369-374. [Czech]

[14] Cort, W. W.: Schistosome dermatitis in the United States (Michigan). J. Am. Medic. Assoc., 1928, 90(13), 1027-1029.

[15] Vogel, H.: Skin lesions caused by Cercaria ocellata. [Hautveränderungen durch Cercaria ocellata.] Dermatol. Wochenschr., 1930, 90, 577-581. [German]

[16] Appleton, C.C.: Schistosome dermatitis - an unrecognized problem in South Africa? S. Afr. Med. J., 1984, 65(12), 467-469.

[17] Kolárová, L., Gottwaldová, V., Cechová, D., et al.: The occurrence of cercarial dermatitis in Central Bohemia. Zentralbl. Hyg. Umweltmed., 1989, 189(1), 1-13.

[18] Várnai, F.: Tropical diseases. 3rd ed. [Trópusi betegségek. 3. kiadás.] Medicina Könyvkiadó, Budapest, 1987. [Hungarian] 
[19] Blankespoor, H. D., Reimink, R. L.: The control of swimmer's itch in Michigan: Past, present, future. Michigan Academician, 1991, 24, 7-23.

[20] Lambertucci, J. R.: Acute schistosomiasis mansoni: revisited and reconsidered. Mem. Inst. Oswaldo Cruz, 2010, 105(4), 422435 .

[21] Bearup, A. J., Langsford, W. A.: Schistosome dermatitis in association with rice growing in the northern territory of Australia. Medic. J. Aust., 1966, 1(13), 521-525.

[22] Liu, C., Chao, S., Niu, S.: A survey of the aetiological agent of rice-field dermatitis with studies on the life-cycle of Orientobilharzia turkestanica var. tuberculata in Jilin Province. Acta Zool. Sinica, 1976, 22, 279-287. [Chinese]

[23] Kotlán, S.: Parasitology. [Parasitologia.] Magyar Országos Állatorvos Egyesület, Budapest, 1944. [Hungarian]

[24] Kotlán, S., Kobulej, T.: Parasitology. [Parazitológia.] Mezőgazdasági Kiadó, Budapest, 1972. [Hungarian]

[25] Halász, I.: Rarer and more obscure suffixes. [Ritkább és homályosabb képzők.] Magyar Nyelvőr, 1880, 9, 257-263. [Hungarian]

[26] Pastinszky, I., Rácz, I.: Skin symptoms of internal diseases. [Belbetegségek bőrtünetei.] Medicina Könyvkiadó, Budapest, 1959. [Hungarian]
[27] Molnár, K., Székely, Cs., Majoros, G.: A case of swimmers' dermatitis caused by fluke cercariae in Hungary. [Métely-cerkáriák okozta bőrgyulladás esete Magyarországon.] Halászat, 2003, 96(2), 80-84. [Hungarian]

[28] Majoros, G., Sztojkov, V.: Appearance of the large American liver fluke Fascioloides magna (Bassi, 1875) (Trematoda: Fasciolata) in Hungary. Parasit. Hung., 1994, 27, 27-38.

[29] Majoros, G., Dán, Á., Erdélyi, K.: A natural focus of the blood fluke Orientobilharzia turkestanica (Skrjabin, 1913) (Trematoda: Schistosomatidae) in red deer (Cervus elaphus) in Hungary. Vet. Parasitol., 2010, 170(3-4), 218-223.

[30] Lawton, S. P., Majoros, G.: A foreign invader or a reclusive native? DNA bar coding reveals a distinct European lineage of the zoonotic parasite Schistosoma turkestanicum (syn. Orientobilharzia turkestanicum) (Dutt and Srivastava, 1955). Infect. Genet. Evol., 2013, 14, 186-193.

[31] Majoros, G., Fehér, Z., Deli, T., et al.: Establishment of Biomphalaria tenagophila snails in Europe. Emerg, Infect, Dis., 2008, 14(11), 1812-1814

(Juhász Alexandra dr., Budapest, István u. 2., 1078 e-mail: juhasz.alexandra89@gmail.com)

\section{Tisztelt Szerzőink, Olvasóink!}

Az Orvosi Hetilapban megjelenő/megjelent közlemények elérhetőségére több lehetőség kínálkozik.

Rendelhetö különlenyomat, melynek áráról bővebben a www.akkrt.hu honlapon (Folyóirat Szerzöknek, Különlenyomat menüpont alatt) vagy Szerkesztőségünkben tájékozódhatnak.

A közlemények megvásárolhatók pdf-formátumban is, illetve igényelhető Optional Open Article (www.oopenart.com).

Adott dij ellenében az online közlemények bárki számára hozzáférhetök honlapunkon (a közlemények külön linket kapnak, így más oldalról is linkelhetővé válnak).

Bővebb információ a hirdetes@akkrt.hu címen vagy különlenyomat rendelése esetén a Szerkesztőségtöl kérhető. 